\title{
The Pitfalls of National Consciousness as Depicted in Matigari by Ngugi wa Thiong'o
}

\author{
Logamurthie Athiemoolam, Assoc Prof. \\ Logamurthie.Athiemoolam@mandela.ac.za \\ Nelson Mandela University, Port Elizabeth, South Africa
}

\begin{abstract}
The paper provides insights into how national consciousness is eroded in post-colonial Africa with reference to Matigari by Ngugi wa Thiong'o and the impact of this erosion on the marginalized, largely impoverished masses, who continue to live on the periphery of society. The African elite (bourgeoisie), who are the new rulers after colonialism, become so obsessed with their own material enrichment and their new found power, that the 'imagined state', for which so many had fought and sacrificed their lives, becomes a mere pipe dream. It is with this background in mind that the paper intends to examine how the pitfalls of national consciousness highlighted by Fanon in his text 'The Wretched of the Earth' find resonance in Ngugi's non-fiction work Matigari and the crucial issues that the text raises in terms of how the new rulers abuse their power and the mechanisms that they implement to entrench their authority. Through Ngugi's use of the fictional protagonist Matigari, we are taken on a journey that unearths the rampant corruption and brute force of the regime as they strive to annihilate any opposition that dare question their abuse of power.
\end{abstract}

Keywords: Post-colonialism, National consciousness, Othering, Oppressive regime

\section{Introduction}

The colonial era in Kenya, like in all other African countries, was characterized by the oppression of the indigenous population by the colonial masters, who not only pillaged the countries of their natural resources, but also reduced the inhabitants to slaves in the countries of their birth. The indigenous population's dissatisfaction with colonial rule led to the emergence of guerilla 'freedom fighters' that waged an armed struggle against their colonial masters. The Mau Mau movement's armed struggle in Kenya to purge their country of colonialism, for example, is well known the world over. It is this struggle that partially led to the liberation of Kenya and the independence of the country from British colonial rule.
The period of independence is characterized by a renewed feeling of national consciousness and optimism that the nation will be galvanized thereby ensuring that the people have a sense of belonging to a country that they can refer to as their own. According to Ozumba (2014:149) national consciousness could be defined as 'identifying with the spirit and aspirations of the nation as one soul in possession of one destiny and one identity.' He further asserts that consciousness forges the identity which in turn drives the spirit of the nation to national greatness. Consciousness is an interconnected process that galvanizes people to the 'metaphysical and physical life of the nation in all its travails because it is in its survival that we gain our survival' (Ozumbza, 2014:150). It does appear as if post-colonial countries in Africa experienced challenges relating to the attainment and sustainability of national consciousness due to, amongst other 
reasons, the rupture between the largely bourgeoisie controlled state and the rest of the population.

In the text Matigari, the protagonist, who had been waging an armed struggle against Settler Williams, representing the British colonialists, decides to bury his AK47 rifle, gird himself with a belt of peace and return to claim his property after the independence of his country from colonial rule. The novel opens with a utopian dream of Kenya as a land of joy, brotherhood and emancipation and the appearance of Matigari out of the dense forest with a hope that the last of the colonial problems had disappeared with a descent of Settler Williams into hell' (Ngugi,1987:3). When he returns to his independent country, however, he finds that very little has changed since the new rulers, comprising largely the African bourgeoisie class, continue to perpetuate the atrocities of the past, thereby ensuring that the marginalized masses remain on the periphery of society. The irony of the hope that he espouses however, constitutes neocolonial Kenya. According to Fanon (1963:152) the neo-colonial mask is the transmission line between nation and capitalism, 'rampant though camouflaged'.

\section{Underdeveloped Middle Class that Emulates the West}

One of the pitfalls of national consciousness highlighted in Matigari is that the African elite, that have assumed power, consist largely of an underdeveloped African bourgeoisie who emulate the west. According to Fanon (1963: 149), the national middle class is an 'underdeveloped middle class' as it does not offer the masses anything different from the colonial era itself. Although it wants to replace the bourgeoisie of the mother country, it has no economic power (Fanon, 1963:149). It eventually however turns to the mother country for support and continues to be part of the racket, since it is not 'engaged in production, invention or building' (Fanon,1963:150). Thus the only difference between the two groups, as pointed out by Addei et.al (2013:21), is that 'the white colonial masters have simply metamorphosed into their own natives, the elite few, who have assumed control.'

The ruling elite in the novel tended to adopt the capitalist system slavishly looked to the west for material and military support and was critical of the African philosophy that favoured the community above the individual. It is precisely their abrogation of the focus on the connectedness among Africans namely Ubuntu, as representing a brotherhood that connects people together, that constitutes one of the pitfalls of national consciousness. The adoption of individualism, which is contrary to African philosophical thought, estranges the masses from the state, as the people in positions of power are only concerned about their own enrichment at the expense of the population at large. This viewpoint on the adoption of individualism as opposed to collectivism is vividly depicted in Matigari when the protagonist tells John Boy, an African who is the co-director of the Anglo American Leather and Plastic Company that he has come to claim his house from Settler Williams, as he built the house and tilled the fields. In his response to Matigari, John Boy, representing the newly established African bourgeoisie, describes the country as remaining in darkness because of the ignorance of the people to 'respect the freedom of the individual, which means the freedom of everyone to follow his own whims without worrying about the others' (49). He describes white people as being more advanced because of their respect for individualism above the community. The notion of 'othering' of the African masses and his cynicism of their worldview is succinctly articulated as follows:

But you black people? You walk about
fettered to your families, clans,
nationalities, people, masses. If the
individual decides to move ahead he is
pulled back by the others (49).

John Boy's viewpoint on individualism is further expatiated on when he quotes the words of the song 'Go your own way and let me go mine, for none of us is carrying the other' (49.) He supports his view further by claiming that his father sent him to school and ignored the idiots who were mumbling nonsense about sharing the last bean (49)'. It is clear from the 
philosophy which he espouses that he has turned his back on his African roots and worldview.

Matigari is dumbfounded by his utterance as he remembers how the community rallied together to support John Boy financially so that he could pursue his studies at Fort Hare University. It is clear that now that John Boy has enriched himself he has forgotten those who contributed to his success, which leads Matigari to say: 'Don't you remember that you intellectuals are greatly indebted to the very masses that you are now calling idiots?' (49)

The adoption of the colonial lifestyle is further highlighted when the Minister for Truth and Justice at the meeting between striking workers and employers is described as 'wearing a dark suit with grey stripes, a tie with an emblem of the ruling party, a red carnation hanging from the lapel of the jacket and a white handkerchief peeping out of the breast pocket' (100-101). Aside from his western attire his commitment to the west is confirmed when he describes himself 'as an African Anglophile and proud of it' (102). He also boasts about his material success that is highlighted by his 'seven-storeyed house, black Mercedes Benz, three swimming pools, saunas modeled on those in Finland and a house decorated with marble from Italy'. It is clear that his notion of success is based on outward material displays rather than on deeper levels of consciousness. This is in line with Fanon's (1963:155) articulation of the undeveloped bourgeoisie as spending large sums of money on outward display such as on cars, country houses and clothing, amongst others. According to Fanon (1963) this group measures success based on what they have achieved materially and is 'quite content to be the Western Bourgeoisie's business agent from whom it has learnt its lessons' (152). In this sense then, as pointed out by Fanon (1963:154), they identify with the decadence of the west by taking on the role of the manager for the Western enterprise.

John Boy's viewpoints are indicative of how different the worldview of the educated African elite is from those of the masses. This entrenches the 'us' and 'them' syndrome further which militates against the notion of national consciousness as a force that could galvanise the nation together.

\section{Obsession with power leads to a dictatorship and oppression}

As the ruling party entrenches its power after years of dominance and corruption it sets up a dictatorship and oppresses the masses, which further leads to an erosion of national consciousness, since the masses feel alienated from the nation and the country as a whole. Its power is entrenched through, as asserted by Fanon (1963:165), the setting up of a one party state, 'jostling and bullying people, rousing anxiety instead of reassuring the nation and intimating to the general population that they are in continual danger'.

In Matigari the party's obsession with power leads to the banning of books and demonstrations, incarceration of critics and activists and the setting up of a dictatorship. Furthermore, all books by Marx and Lenin are banned, students are detained without trial for having seditious documents, strikes and gatherings are banned by a presidential decree and the President decides to set up a one party state as an opposition party is deemed irrelevant and insignificant. When the rumour spreads amongst the masses that Matigari, loosely translated as 'the patriots who survived the bullets', has supernatural powers and has come back to free them from oppression like Christ, the government responds by indicating that it will not hesitate to clamp down on any religion claiming that Christ has come back (84). This unfettered arrogance is further substantiated when the radio broadcast asserts that 'there is no way that Jesus could return without first going to pay a courtesy call on the president' (84). The fact that Matigari, the protagonist, is characterised as a saviour who has returned to liberate the masses from oppression is cause for concern among the rulers as it serves to threaten its hold on political power. Hence via the news broadcast the ruling party urges the public to report anyone claiming to be Jesus or Gabriel to the nearest police station (84).

It is clear that through the writing of the novel Matigari, Ngugi is eager to illustrate how 
the neo-colonial government, represented by the political party in this case the KKK use their power to jostle and bully the workers and dissidents. This is vividly portrayed at the meeting convened by the Minister of Truth and Justice between the workers and employers when the Minister declares all strikes against the Anglo American Leather and Plastic Company illegal after receiving shares for both him and the president from the directors. In his veiled threats to the workers he warns them that 'anyone who strikes against the company will actually be striking against the government', 'provoking the company will be exactly the same as sticking a finger in the nose of the ruling party'and 'hurling abuse at this company is the same as hurling insults to the nation'(108). The abuse of power in this way constitutes the hallmark of an autocratic regime determined to instil fear and anxiety among the workers. This clearly constitutes the absolute abuse of power which Fanon (1963:165) describes as 'unmasked, unpainted, unscrupulous and cynical'. Through the setting up of a dictatorship and the silencing of the masses the bourgeoisie state has effectively stifled any attempt at achieving any sense of national consciousness amongst the population at large.

\section{Government intimidates the workers and uses force to restrain the masses}

The government in Matigari sees the marginalized masses as a threat to the stability of the country and tries to restrain them through propaganda, force and intimidation which further affect nation building and the development of national consciousness. According to Fanon (1963:182), 'the incoherent mass of people is seen as a blind force that must be continually held in check either by mystification or by the fear inspired by the police force.' The family coat of arms adopted by the Minister of Truth and Justice in which a coffee bush is guarded over by two whips below which is the family motto: 'Destroy Terrorists', symbolizes the brute force that has become the hallmark of a failed state devoid of any sense of national consciousness.
The workers in Matigari are kept in check through intimidation, incarceration and brute force represented by the army and the police. The meeting convened by the Minister for Truth and Justice between workers and the employers to resolve the strikes becomes a forum for sentencing the escaped prisoners and intimidating and incarcerating others who questioned and challenged the Minister. At this meeting the Minister describes himself as 'the soul of this government and the nation' and 'the torch of development' (100), thereby emphasizing his role as the unilateral custodian of law and order. In the same breath he commands the workers to end the strike and return to work and requests that the company take back all the workers with the exception of the ringleaders (100). The fact that armed policemen were stationed inside the hall and riot-control police and a unit of the army stood ready for battle outside highlights the government's tactics to instill fear in the workers so that they would remain subservient and passive. If they were a worker's government as the Minister states, then the deployment of the police force and the army would be unnecessary. According to Fanon (1963:171) the government reinforces the machine by 'ensuring that people are hemmed in and immobilized' by exhibiting forces to prove to itself and to others that 'the people are behind it'. It is clear that this strategy is one of intimidation to ensure that the general population remains under its control.

The meeting showcases the might of the ruling party namely the KKK with the parrot emblem and the Minister together with the party's mouthpieces sing the praises of the party. The party's successes are extoled and its agents applauded for their commitment and dedication to the party's mission and vision. The focus of the party at this forum, as asserted by Fanon (1963:171), is to ensure that the government 'holds the people down'. In this sense then the party and the government are indistinguishable.

In order to intimidate and instil fear in the masses we hear through the Voice of Truth over the radio broadcast that all gatherings of more than five people have been banned by a decree of the president. Furthermore when 
discontentment amongst the masses becomes more visible the 'government becomes harsher and the army becomes the arbiter' (Fanon, 1963:174). At the meeting when students start to sing the song 'Victory belongs to the people' (122) they are reminded by the Minister that since this village was under the control of the chief they should sing from the official hymn-book, Songs of a Parrot.

Later when Ngaruro wa Kiriro, leader of the workers, questions the banning placed on workers' meetings and Matigari inquires about where in the country he could find peace and justice and demands his land back, the Minister decides at the meeting that since they have the audacity to brazenly express their feelings they must be deranged and banishes both to mental institutions. When Matigari was handcuffed by the police the crowd commenced with the singing of freedom songs associated with the freedom fighters (Matigari). In the novel Matigari, the protagonist, represents all freedom fighters and the Minister of truth and Justice represents the corrupt judiciary. The minister immediately passes a decree to ban all songs about the freedom fighters. The absolute power that is vested in the hands of the minister leads him to pass a new law banning all songs about Matigari ma Njiruungi and all dreams. According to the minister 'All subversive songs and dreams are banned' (125). This unilateral law, which is summarily passed at the meeting, highlights the absolute power that the government exerts over the masses. However when the people rose as one to sing the freedom song and moved as if they wanted to free Matigari from the room where he was being handcuffed, the police commissioner blew the whistle and there was pandemonium. The brute force is depicted by the manner in which the police force and the army came rushing in and driving the people out with the butts of their guns. Later when the riots break out in Part 3 of the novel entitled the 'Pure and the Resurrected' and houses are burned, the government uses brute force and gunshots could be heard from all sides. When the President hears about the outbreak of violence amongst the masses he promulgates a new law 'Shoot on sight. Shoot to kill'. According to Fanon (1963:166) before independence the leader embodies the aspirations of the people for independence, political liberty and dignity. However after independence he becomes the leader of the group of profiteers and exploiters, and judges the ingratitude of the masses harshly thereby prompting him to use brute force to keep them under control.

Later when both Matigari and Ngaruro are able to escape from the mental institute supported by Guthera, who is forced into prostitution, and the young boy Muriuki, the Voice of Truth through the radio broadcast requests the public to 'report to the nearest police station anybody found speaking like a madman or dressed in rags like a madman, or anyone with unkempt hair like a madman's or anyone seen asking awkward questions like a madman or doing things which only a madman would do' (133). The ludicrousness of the announcement indicates how the state tries to instill anxiety amongst the population at large which creates a degree of instability within the country as a whole.

It is clear that the government's use of force to control the masses, the promulgation of laws to restrict freedom of expression, the incarceration of perceived militants and the intimidation of striking workers creates a very volatile environment thereby estranging the masses from the government even further thereby contributing to the annihilation of national consciousness. The masses perceive themselves as outsiders who do not have a say in the government at large thus leading to their disconnectedness from the state.

\section{Corruption within the Ruling Party and the State.}

The ruling party that assumes power after independence degenerates into a corrupt party as it becomes embroiled in scams involving foreign capitalists. This corruption becomes endemic and spreads like wildfire amongst the members of the party and the government as a whole thereby leaving the country in a state of paralysis. In the meantime the marginalized masses remain frustrated, demotivated and are forced to live on the periphery of society. This, according to Fanon (1963:171), leads to an extreme inequality in 
wealth and monopolization as some of the members of the party have a double source of income and demonstrate that they are specialists in opportunism. In this way, as pointed out by Fanon (1963:164), they hasten to make their own fortunes and set up a national system of exploitation. The corruption is vividly portrayed in Matigari when the two directors of Anglo American Leather and Plastic Company, Robert Williams and John Boy, hand over two certificates of shares; one for the Minister for Truth and Justice and the other for the President. They also hand over a cheque to the value of 50000 shillings towards the special presidential fund for handicapped children. As a token of appreciation for the shares, the Minister for Truth and Justice declares all strikes against the company illegal. Fanon(1963) describes the scandalous enrichment as 'speedy and pitiless' (167).The shares that are awarded to the minister are a sign of the corrupt relationships between members of the party and the capitalists. According to Fanon (1963:165) since the party does not share profits with the people and allow them to enjoy the dues that are paid to it by the big foreign companies, the 'country sinks all the more deeply into stagnation'. The rampant corruption leads to widespread poverty and dissatisfaction with the ruling party. However the bourgeoisie becomes immune to corruption as privileges multiply and morality declines. This is further exacerbated by, as pointed out by Fanon (1963), a largely absent president who closes his eyes to mediocrity and fundamental immorality of the ruling class (165).

In Matigari, for example, the latter is depicted when the wife of the Minister for Truth and Justice is caught red handed having sex with her driver. Yet she was the very same lady who spoke out against promiscuity and the importance of remaining loyal to one's partner as espoused in the Bible. At the meeting with workers the Ten Commandments are re-inforced by the very party whose members are responsible for breaking most of them anyway. Through a focus on such incidences in the novel Ngugi aims to make us aware of how deep rooted corruption is and that it has the potential to permeate every level of human existence and of society at large.

Matigari's experiences in the post-colonial country have led him to realise that the world is upside down and that 'in our land today lies are decreed to be the truth and the truth decreed to be a lie'(97). Since returning from the forest to the post independent country he has been exposed to corruption in all its guises from material to sexual favours and on all strata in society, from policemen to ministers' wives and the ministers themselves. These experiences, as pointed out by Fanon (1963:172), are reminiscent of post- colonial African countries as 'Scandals are numerous, ministers grow rich, their wives doll themselves up, the members of parliament feather their nests - everyone including policemen and customs officials join in the corruption'. Through his experiences Matigari has come to realize that in the society that he finds himself in 'privileges tend to multiply and corruption triumphs while morality declines' (Fanon, 1963:171).

In reflecting on his experiences Matigari is left bewildered and confused as to how unequal this society is. While the bourgeoisie live in the lap of luxury in their posh suburbs, children are living in abject conditions in derelict cars rummaging in garbage for food.

This prompts him to pose the question: 'Where could a person wearing the belt of peace find truth and justice in post- colonial society?' (Ngugi: 16). Another question which he ponders over is 'Had anything really changed between then and now'? In his search for responses to the questions he discovers that the 'expected discontinuity between the colonial and post-colonial times is illusory' (Breidlid, 2005) and that the true liberation of the masses economically, politically and intellectually remains a pipedream. His numerous depressing experiences after returning from the liberation struggle in the forest leads him to question any notion of a 'new land'. In his search for truth and justice he discovers that 'a handful of people profited from the suffering of the majority' and that 'the few gained joy out of the sorrow of the many'. According to Addei et al. (2013:21) the postindependence in Africa is plagued by 'social corruption, autocracy, a foreign dominated 
economy as well as the betrayal of human ideals among others'. In reflecting on the corruption within post independent African countries Fanon describes the problem as overwhelming and reprehensible as 'Today the vultures are too numerous and too voracious in proportion to the lean spoils of national wealth' (171). The gross inequality in society partially ascribed to the blatant corruption and misappropriation of funds serves as an obstacle to national unity and consciousness.

\section{The country is controlled by local and foreign capitalists.}

According to Fanon (1963) the mother country and foreign companies do not 'mask the hold [they have] on the national government (167)'. This is highlighted in Matigari when the Minister for Truth and Justice invites delegates from the USA, Britain, West Germany and France as well as the directors of the Anglo American Leather and Plastics Company, represented by Robert Williams and John Boy, to the meeting convened by him to deliberate on the strikes in the country. They are invited since the country, according to him, "has a good international image in the West because of its rule of 'truth and justice' (100). This is ironic as the policies and strategies that the country has employed to oppress the masses is anything but just. In this way Ngugi wants to illustrate that the foreign and local capitalists are as corrupt and unjust as the government.

The unfettered support and blind allegiance to the local and foreign capitalists is demonstrated when the all-pervading Minister for Truth and Justice declares a blanket ban on all strikes against the aforementioned company after he and the president receive personal certificates for shares in the company. At the same meeting when Matigari requests that the land and the house that he fought for be returned to him he is admonished by the Minister for Truth and Justice, handcuffed, declared to be a madman and banished to a mental institution. It is then that Matigari realizes that most of the things that he had fought for, especially the land and the house, still remain in the hands of the imperialists and their African capitalist counterparts. In this sense it is clear that the new regime have 'annexed the wealth of the country for its own profit' (Fanon, 1963:167). Matigari also further realizes that the Kenyan elites have betrayed the Mau Mau struggle by colluding and collaborating with the western capitalists thereby ensuring a return to colonization. What is clear to Matigari is that Settler Williams and his servant John Boy, against whom he had waged a war in the forests for so many years, have now been replaced by their sons Robert Williams and John Boy Jnr who have formed an alliance to oppress the masses by 'reaping what they do not sow' (12).

According to Fanon (1963:167) the foreign companies and the mother country do not 'mask the hold that [they have] on the national government'. This is vividly depicted in Matigari when we hear via the news bulletin that 'Britain and the European Community have given the country a loan of several million pounds for the development of the administration of instant justice [and that] the loan will be used to buy handcuffs, hand and leg chains, uniforms for prison warders, electric fences to help guard the prisons and ropes for hanging those who have been sentenced to death.' The proviso however is that all the material 'must be bought from British factories or from other EEC countries (132)'. The latter proviso is indicative of the obligating compliance that is expected by foreign capitalists and the mother country from the newly independent state (Fanon, 1963:165).

The desperation of the government to control the restless masses in Matigari leads them to seek assistance from the USA to represent their cause at the IMF and World Bank. It is clear that the government perceives the use of military force through the support of the USA as the only means of suppressing the uprisings in the country as succinctly depicted in the news broadcast below:

'...the USA requests the World Bank and the IMF to give the country a loan for the development and the defence of the rule of law, truth and justice' (132). 
However the hidden agenda is the obligating compliance highlighted by Fanon (1963) on the state to purchase military vehicles from the US with the money received from the World Bank. This is clearly illustrated in the follow up broadcast in which the US government indicates that it 'would be willing to listen with sympathy to a request to supply this country with Phantom jets, tanks and attack helicopters (132).' This is one of the ways in which foreign capitalists, as pointed out by Fanon (1963:167), are able to control the economy. The economic hold that capitalists have on the country and the privileges that they enjoy militate against any possibility of galvanizing the nation into a coherent force thereby leading to greater polarization and discontentment amongst the citizens of the country. Consequently as a result of the government's support to foreign capitalists any notion of the advancement of national consciousness in the country as a whole becomes a mere pipedream.

\section{The degeneration of the party and disconnectedness from the masses.}

According to Fanon (1963:170) national consciousness is severely impacted as the party creates a screen between the masses and the leader and becomes disconnected from the people. In Matigari, for example, the Minister for Truth and Justice speaks on behalf of the president who is largely absent from any gatherings. His pronouncements and decrees are mainly communicated through the media which becomes an organ of propaganda for the national government.

Fanon (1963:171) describes the party as 'a skeleton of its former self' which is 'falling to pieces' due to the members' pursuits of individual interests and private advancements. In Matigari the Minister for Truth and Justice is pre-occupied with his alliance with western governments and capitalists for his own personal aggrandizement as depicted by his attitude when he receives the shares from the Anglo American company.

Ngugi's characterisation of the party in Matigari in satirical terms such as the use of the parrot as the emblem of the party, demonstrates the blind allegiance which the party expects from its followers, institutions and organs of the state. Those who were present at the meeting included the editor of the newspaper the Daily Parrotry, a professor of the history of parrotology and a university lecturer who had a B.Ed, MA and a PHD in the philosophy of Parrotology (101). The followers of Parrotology sang out of a hymnbook entitled Songs of a Parrot which had been composed by a group of specialists in the voices of parrots. In addition to the above mentioned institutions Ngugi also highlights how the church is drawn into the web of deceit and Parrotology through the priest's prayer in which he requests the Lord to 'still the hearts of the employers and those of the workers so that they may all be satisfied with the decisions arrived at through truth and justice' (101). The Priest's reference to truth and justice is a clear indication of his close relationship with the Minister for Truth and Justice whom we hear from the priest contributes generously to the church and attends services regularly and religiously.

Through the use of the extended metaphor focusing on parrots Ngugi aims to demonstrate how the post-colonial state is able to control the media and the university to promote the ruling Party's image which is on the decline. Ngugi's use of the Parrot as an emblem for the party is very apt as he extends the metaphor to demonstrate how the loyalists, who extol the praises of the party like parrots, are rewarded. This is done at the meeting when the Minister of Truth and Justice announces that all loyalist professors and 'all holders of Ph.ds in Parrotology' are to be promoted and given permanent professorships (103). According to the minister these professors are different from others who are always raising a hue and cry about revolution as they 'are the ones who know how to obey and abide by the law, how to serve the law' (103). According to Fanon (1963:171) the party's obsession with making all the decisions on behalf of the people through rewarding blind allegiance and using brute force to keep detractors at bay signifies the collapse of the nation state.

In Matigari the disconnectedness of the people from the party is further advanced by 
the manner in which the party tries to control the people from the summit by taking their voices away from them. This is aptly demonstrated at the meeting when the Minister for Truth and Justice does not brook any opposition to his decrees and uses brute force to silence the people from singing songs in praise of Matigari. He unilaterally bans the songs and summons the military to repress the crowd. The autocratic attitude displayed by the Minister for Truth and Justice at the meeting clearly demonstrates the disconnectedness between the state and the ordinary masses. According to Fanon (1963:171) when the party issues instructions from the summit and does not include the people, the people become alienated from the party and in this way any attempt at achieving national consciousness is thwarted and the nation effectively disintegrates into oblivion.

\section{Hostility towards the ruling party leads to restlessness amongst the masses}

National unity within the country as a whole, after post colonialism, is negatively affected due to the malaise of corruption and the government's adoption of despotism as a means of controlling the masses. This leads the general population to becoming increasingly restless and disenchanted with a party that has become a shadow of its former self and to protest against the government's laws and imperialists' monopolization of the economy. According to Fanon (1963) although the leader urges people to place confidence in him because of what he and the party has done in the past and is continuing to do (168) to mask what is happening in the country, the masses have no illusions of what is happening (169). However they catch on to its propaganda, begin to sulk and turn away from the nation in which they have been given no place and begin to lose interest in it (169). According to Fanon (1963) their disappointment with the ruling bourgeoisie and hostility towards them is played out through protests and the revival of a new struggle against what is perceived as an oppressive regime. This new struggle which starts off with the revival of protest songs from the past leads to violent confrontation as they become increasingly disenchanted with the ruling party.
The dissatisfaction of the nation with the heartlessness of the regime is aptly summed up by one of the prisoners in the prison where the true story of the land is being told:

Our country is truly as dry as this concrete floor. Our leaders have hearts as cold as that of Pharaoh. Or even colder than those of the colonialists. They cannot hear the cry of the people. (55).

The focus on the leaders' 'cold hearts' and their inability to hear the 'cry' of the nation is a clear indication that they have become disconnected from the people and that there is a realization among the people that they do not care, are heartless and ruthless. This reawakening on the part of the nation according to Fanon (1963:167) leads to 'stormy days and restlessness'.

Towards the end of the novel when Matigari drives to John Boy's house to claim the property as his own in the stolen Black Mercedes owned by the Minister of Peace and Justice's wife, he was stunned to notice that the 'whole country seemed to be assembled there' (163). The space was inundated by cars, soldiers carrying guns and torches and policemen walking around with their dogs. The realization on the part of the state to growing hostility and antagonism to their style of leadership in the novel leads to paranoia on their part as manifested in the unleashing of a large contingent of security personnel to apprehend one person. When Matigari was commanded to come out of the house, the assembled crowd all chanted his name in unison and were threatened by the Paramilitary Shooting Unit that if they cheered again they would be shot down 'there and then' (165). The use of military force to curb the masses for merely chanting or singing freedom songs is a sign that the state has become antagonistic towards the nation as a whole who depended on it to galvanize the nation together thereby facilitating national consciousness. However instead of instilling a sense of patriotism on the part of the people to the nation as a whole the state has created a schism between them and the people through its aggressive actions and confrontational strategies thereby alienating the people from them even further. 
In Matigari the rupture between the government and the people leads to the riot that ensues at John Boy's house after the house is set alight. The realization on the part of the people that they are alienated from the capitalist system leads them to chant: 'Bad boy's house is burning. Let's warm ourselves with it'(166). After the Mercedes also bursts into flames and adds to the brightness of the fire, the crowd becomes even more uncontrollable and the children living in the derelict cars take the lead in shouting out that the other houses should also burn and that 'everything that belongs to these slaves must burn!' When the call becomes a refrain the rest of the people make torches from the burning house chanting that the property of those robbing the masses must burn and that the culture of parrotology in the land must burn.'(168).The ensuing violence leads to the burning of houses, tea-bushes, coffee-trees and vehicles.

As the people demonstrate their anger against the government and burn property they articulate, through their vocal protests, how the government is stifling and suppressing them by their oppressive laws such as detention without trial, the exiling and incarceration of patriots and students in prisons and their imposition of Parrotology on the population at large. This outbreak of civil unrest prompts the President ('His Excellency, Ole Excellency) to promulgate a new law that instructs the security forces to 'Shoot to kill' (169).

The restlessness amongst the masses that degenerate into violent protests leading to the damage to property heralds a new dawn in the nation state as the people realize that they are not prepared to accept the policies, actions and approaches of the ruling party and that they can no longer accept the government's deception. During this phase of the nation state, characterized by increasing dissatisfaction with the government represented by the party, there is a realization that the state has failed the people thereby signaling a complete disintegration of national consciousness which is the hallmark of a failed state.

\section{Conclusion}

Ngugi demonstrates through the writing of the novel Matigari that the post-colonial state, in many ways emulates the colonial regime in the adoption of capitalism, the creation of a ruling bourgeoisie, the corruption within the state and the exploitation of the masses for personal gain. The marginalization and alienation of the masses from meaningful involvement in the creation of the nation state and the assumption of power on the part of the ruling party militates against any notion of national consciousness that has the potential to galvanize the nation together as a whole. It is clear that the numerous pitfalls of national consciousness identified by both Fanon in the Wretched of the Earth and Ngugi wa Thiong'o in Matigari serve to polarize the nation thereby leading to a schism between the government and the people which serves to thwart any conception of national consciousness amongst the population at large.

The attainment of national consciousness hinges on the newly formed state to engage the masses by raising their level of thought through political education so that they can take up their rightful roles in society at large. According to Fanon the masses need to be made aware from the very outset that the building of national consciousness is a collective act and that no famous person can take responsibility for everything, "but that the demiurge is the people themselves and the magic hands are finally only the hands of the people' (197). According to Fanon for national consciousness to be realized in a newly emerging state after post colonialism collective responsibility is imperative otherwise as highlighted in Matigari there is anarchy, repression, the resurgence of tribal parties and federalism'(204). The success of the nation and the development of national consciousness within the newly formed state are dependent on the moving consciousness of the entire population which, according to Fanon, is the 'coherent, enlightened action of men and women.'(204) 


\section{References}

Addei, Cecilia, Cynthia Osei, and Felicia Annin, 2013. Ngugi and Post Colonial Africa: History, Politics and Morality in Petals of Blood and Matigari. International Journal of Scientific Technology, 2, 9 (2013): 164171.

Breidlid, Anders. "Ngugi's Matigari, a NonMaterialist Discourse and PostModernism." The Australian Journal of Trans-national Writing 1(2005): 1-9.

Fanon, Frantz. The Wretched of the Earth. Translated by Constance Farrington. New York: Grove Weidenfeld, 1963.

Ngugi wa Thiong'o. Matigari. Translated from Gikuyu by Wangui wa Goro. Nairobi: East African Educational Publishers, 1987.

Ozumba, Godfrey.O. National Consciousness, Value Reorientation and Identity: An Integrative Humanist Approach. Journal of Integrative Humanism (2014): 147-155. 